\title{
IMPLEMENTASI SISTEM INFORMASIKONSULTASI KEBUTUHAN GIZI PADA IBU HAMIL DENGAN METODE COOPER BERBASIS WEB PADA PUSKESMAS BUNGUS TELUK KABUNG PADANG
}

\author{
Hendra Nusa Putra \\ STIKES Dharma Landbouw Padang \\ nusahendra@gmail.com, stikesdl@gmail.com \\ DOI: http://dx.doi.org/10.31869/rtj.v2i2.1470
}

\begin{abstract}
This research was motivated by the problem of lack of knowledge and awareness of the nutritional needs of pregnant women during pregnancy at Bungus Teluk Kabung Padang Health Center. Pregnant women rarely do nutritional counseling to nutritionists about the diet and type of food that must be consumed during pregnancy because of limited time for consultation at Bungus Bay Kabung Health Center. Therefore nutritionists try to make the application of nutritional needs of pregnant women web-based with Cooper's method with the aim of making it easier for pregnant women to find information about nutritional intake through food menu selection. The Cooper method is a way of calculating the number of calories needed by a pregnant woman. The method used for system development is the system development life cycle method (SDLC), while the tools for modeling use UML (Unified Modeling Language). The programming language used for making this application is PHP and MySQL for the database. Based on this study, pregnant women can conduct online consultations as a means of providing solutions to find out the fulfillment of the nutritional needs of pregnant women and fetuses.
\end{abstract}

Keywords: Nutritional Needs of Pregnant Women, Cooper Method, UML.

\section{PENDAHULUAN}

Latar Belakang

Gizi dan Nutrisi ibu hamil merupakan hal penting yang harus dipenuhi selama kehamilan berlangsung. Kebutuhan gizi merupakan masalah kecil yang sebenarnya sangat penting karena gizi dan kalori setiap orang harus terpenuhi dengan cukup setiap harinya. Bila status gizi ibu normal pada masa sebelum dan selama hamil kemungkinan besar akan melahirkan bayi yang sehat, cukup bulan dengan berat badan normal. Dengan kata lain kualitas bayi yang dilahirkan sangat tergantung pada keadaan gizi ibu sebelum dan selama hamil.

Masalah gizi merupakan salah satu penentu utama kualitas sumber daya manusia. Zat gizi dibagi ke dalam 3 golongan berdasarkan fungsinya yaitu: (1).Zat Tenaga terdiri dari karbohidrat dan lemak, (2).Zat Pembangun terdiri dari protein dan mineral, (3).Zat Pengatur terdiri dari mineral, vitamin, dan air. Macam - macam zat gizi terdiri dari : 1.Karbohidrat, 2.Protein, 3.Lemak, 4.Vitamin, 5.Mineral. Kekurangan gizi akan menyebabkan kegagalan pembentukan fisik dan terjadinya gangguan kecerdasan, menurunkan produksifitas kerja, menurunkan daya tahan tubuh serta meningkatkan angka kesakitan dan kematian tinggi dibandingkan yang tidak kekurangan gizi saat mengandung.

Metode Cooper adalah cara menghitung jumlah kalori yang dibutuhkan ibu hamil. Metode Cooper menghitung jumlah kalori dengan mengolah berat badan ideal ibu hamil, aktifitas ibu hamil, serta jumlah jam tidur ibu hamil. Tahap - tahap mengukur jumlah kalori (nutrisi) yang dibutuhkan ibu hamil ada beberapa tahap. Tahap pertama dengan menghitung berat ideal dari ibu hamil tersebut. berat badan ideal didapatkan dari perhitungan antara tinggi badan dan usia kandungan. Tahap kedua dengan menghitung jumlah kalori dapat dihitung setelah berat badan ideal ibu hamil telah diketahui sistem melalui pemilihan menu makanan ibu hamil melalui website. Menurut Poedysmoro (2005) rumus untuk menghitung jumlah kalori yang dibutuhkan ibu hamil dengan metode COOPER adalah sebagai berikut: 


\begin{tabular}{llll}
\hline BM & $:$ & $1 \mathrm{Kal} * 24 * \mathrm{BBIH}$ & $=\mathrm{A} \mathrm{Kal}$ \\
K.Tidur & $:$ & $10 \% * 7-8 \mathrm{Jam} * \mathrm{BBIH}$ & $=\mathrm{B} \mathrm{Kal}+\mathrm{C} \mathrm{Kal}$ \\
Aktifitas & $:$ & $\%$ Aktifitas $* \mathrm{C} \mathrm{Kal}$ & $=\mathrm{D} \mathrm{Kal}+\mathrm{E} \mathrm{Kal}$
\end{tabular}

$$
\mathrm{BBIH}=\mathrm{BBI}+\left(\mathrm{UH}^{*} 0,35\right)
$$

Berdasarkan hal tersebut penulis berpendapat perlunya dibuat sebuah sistem informasi atau software yang dapat mempercepat dan mempermudah kinerja Puskesmas dalam memberikan informasi pemenuhan gizi melalui konsultasi online dengan pemilihan menu makanan ibu hamil melalui website sebagai sarana alternatif di Puskesmas. Dengan berbasis website ini diharapkan dapat memberikan solusi pemenuhan gizi melalui pemilihan menu makanan yang lebih menarik dan interaktif .

Berdasarkan uraian diatas maka penulis memberikan solusi dengan merancang Software KonsultasiKebutuhan Gizi pada ibu hamil Melalui Pemilihan Menu Makanan Menggunakan Metode Cooper Berbasis Website pada Puskesmas Bungus Teluk Kabung Padang bertujuan untuk memudahkan dalam mencari informasi tentang asupan gizi melalui pemilihan menu makanan.

\section{Identifikasi Masalah}

1. Bagaimana menentukan kebutuhan gizi pada ibu hamil ?

2. Bagaimanakah peranangizi dan faktor yang mempengaruhi gizi ibu hamil ?

3. Bagaimana menentukan menu makanan yang memenuhi kebutuhan gizi ibu hamil ?

4. Bagaimana merancang sistem software konsultasi gizi pada ibu hamil berbasis Website?

5. Bagaimana sistem yang terintegrasi dan terorganisasi dengan baik dalam penyampaian informasi ?

\section{Hipotesa}

Dalam menyelidiki masalah, tentu sudah umum diketahui bahwa kita harus mempunyai asumsi-asumsi dan rumusanrumusan yang sifatnya sementara tentang masalah yang akan dibahas tersebut. Adapun hipotesa dari masalah ini adalah :
1. Sistem informasi Kebutuhan Gizi pada Ibu Hamil diharapkan dapat memaparkan secara umum kebutuhan gizi yang diperlukan oleh ibu hamil.

2. Sistem informasiKonsultasiKebutuhan Gizi pada Ibu Hamil diharapan dapat memberikan informasi status gizi dan faktor yang mempengaruhi gizi ibu hamil.

3. Sistem informasi KonsultasiKebutuhan Gizi pada Ibu Hamil diharapkan dapat memberikan solusi menu makanan sehat berdasarkan jumlah kalori yang dibutuhkan oleh ibu hamil.

4. Sistem informasi KonsultasiKebutuhan Gizi pada Ibu Hamil dengan Metode Cooper Berbasis Webdiharapkan bisa menjadi sebuah wadah informasi yang dapat dipercaya.

\section{Batasan Masalah}

Agar penelitian dan penganalisaan ini terarah dan permasalahan yang di bahas tidak keluar dari topik pembahasan maka perlu adanya batasan ruang lingkup permasalahan. Dalam hal ini penulis membatasi penelitian dan penganalisaan ini antara lain :

1. Cara menentukan kebutuhan gizi pada ibu hamil

2. Peranan gizidanfaktor yang mempengaruhigiziibuhamil

3. Menentukan menu makanan yang memenuhikebutuhangiziibuhamil

4. MerancangSoftwareKonsultasiGizipadaI buHamildenganMetodeCooperBerbasis Web

\section{Tujuan Penelitian}

Adapun tujuan dari penelitian ini adalah sebagai berikut :

1. Untuk menentukan kebutuhan gizi pada ibu hamil.

2. Untuk mengetahui peranan status gizi dan faktor yang mempengaruhi gizi ibu hamil. 
3. Untuk menentukan menu makanan yang memenuhi kebutuhan gizi ibu hamil.

4. Terciptanya software Kebutuhan Gizi pada Ibu Hamil dengan Metode Cooper Berbasis Web

\section{Metode Penelitian}

Metodologi ini dilakukan dengan dua cara yaitu observasi dan wawancara.

1. Metode Observasi (Observation Method) Pengumpulan data melalui pengamatan secara langsung terhadap objek ini dilakukan dengan maksud agar dapat mengetahui tentang cara, prosedur, pelaksanaan data secara langsung sehingga mengetahui secara jelas segala permasalahan yang berkaitan dengan system yang akan dirancang pada Puskesmas Bungus Teluk Kabung Padang dalam hal kebutuhan gizi ibu hamil.

2. Wawancara (interview)

Metode pengumpulan data dengan mengadakan Tanya jawab langsung terhadap pihak yang berkaitan di Puskesmas Bungus Teluk Kabung Padang antara lain bagian medis pada gizi dan ibu hamil.

\section{LANDASAN TEORI Definisi Sistem}

Sistem didefinisikan sebagai sekumpulan prosedur yang saling berkaitan dan saling terhubung untuk melakukan tugas bersama-sama. Secara garis besar, sebuah sistem informasi terdiri atas tiga komponen utama. Tiga komponen tersebut mencakup software, hardware, dan brainware. Ketiga komponen ini saling berkaitan satu sama lain (I Putu Agus Eka Pratama, 2014:7).

\section{Definisi Informasi}

Informasi merupakan hasil pengolahan data dari satu atau berbagai sumber, yang kemudian diolah, sehingga memberi nilai, arti, dan manfaat . Pada proses pengolahan data, untuk dapat menghasilkan informasi, juga dilakukan proses verifikasi secara akurat, spesifik, dan tepat waktu. Hal ini penting agar informasi dapat memberi nilai dan pemahaman kepada pengguna (I Putu Agus Eka Pratama, 2014:8).

\section{Definisi Sistem Informasi}

Sistem informasi merupakan gabungan dari empat bagian utama. Empat bagian utama tersebut mencakup perangat lunak (software), perangkat keras (hardware), infrastruktur, dan Sumber Daya Manusia (SDM) yang terlatih. Keempat bagian utama ini saling berkaitan untuk menciptakan sebuah sistem yang dapat mengolah data menjadi informasi yang bermanfaat. Di dalam nya juga termasuk proses perencanaan, kontrol, koordinasi, dan pengambilan keputusan (I Putu Agus Eka Pratama, 2014:10).

\section{Siklus Hidup Pengembangan Sistem (SDLC) SDLC atau Software Developemnt Life} Cycle atau sering disebut juga Sistem Developmen Life Cycle adalah proses pengembangan atau mengubah suatu sistem perangkat lunak dengan mengunakan modelmodel dan metodelogi yang digunakan orang untuk mengembangkan sistem-sistem perangkat lunak sebelumnya (berdasarkan best practice atau cara-cara sudah teruji baik). Seperti halnya proses metamorfosis pada kupukupu, untuk menjadi kupu-kupu yang indah maka dibutuhkan beberapa tahap untuk dilalui, sama hal dengan membuat perangkat lunak, memiliki daur tahapan yang dilalui agar menghasilkan perangkat lunak yang berkualitas. (A S, Rosa dan M. Shalahuddin. 2015:25).

\section{Kehamilan}

Istilah medis untuk wanita hamil adalah gravida, sedangkan manusia didalamnya disebut embrio pada masa awal kandungan dan kemudian disebut janin sampai kelahiran. Seorang wanita yang hamil untuk pertama kalinya disebut primigravida atau gravida 1 . Seorang wanita wanita yang belum pernah hamil dikenal sebagai gravida 0 . Pada dunia medis kehamilan manusia dibagi menjadi tiga periode triwulan, sebagai cara memudahkan tahap berbeda dari perkembangan janin. Triwulan pertama membawa resiko tertinggi keguguran (kematian alami embrio atau janin), sedangkan pada masa triwulan kedua perkembangan janin dapat dimonitor dan didiagnosa. Triwulan ketiga menandakan awal viabilitas, yang berarti janin masih dapat tetap hidup bila terjadi kelahiran awal alami atau 
kelahiran dipaksakan. Karena kemungkinan viabilitas janin yang telah berkembang.

\section{Kebutuhan Gizi Ibu Hamil}

Nutrisi adalah makanan dan zat gizi dalam makanan yang berguna bagi kesehatan. Zat gizi atau nutrien merupakan zat - zat makanan yang terkandung dalam suatu bahan panganyang dapat dimanfaatkan oleh tubuh.

Faktor-faktor yang mempengaruhi status gizi ibu hamil adalah:

1. Tinggi Badan

Tinggi badan pada wanita hamil dapat digunakan untuk mengukur status gizi sebelum terjadi kehamilan.

2. Berat Badan

Metode untuk untuk mengetahui status gizi ibu hamil melalui pertambahan berat badan yang optimal selama masa kehamilan adalah penting untuk mengetahui BMI (Body Mass Index) wanita prekehamilan.

3. Gizi dan Nutrisi Ibu Hamil

Gizi disebut juga nutrisi, merupakan ilmu yang mempelajari perihal makanan serta hubungannya dengan kesehatan. Gizi dalam masa kehamilan sangat penting, bukan saja karena makanan yang diperoleh mempengaruhi kesehatan ibu dan bayi, tetapi juga berpengaruh saat menyusui nanti. Kebutuhan energi untuk kehamilan yang normal perlu tambah kira-kira 80.000 kalori selama masa kurang lebih 280 hari.

4. Kebutuhan Gizi Ibu Hamil

Zat-zat gizi penting yang dibutuhkan ibu selama hamil sebesar 2500 kalori per hari.

\section{Metode Cooper}

Tahap - tahap mengukur kalori (nutrisi) yang dibutuhkan ibu hamil ada beberapa tahap. Tahap pertama dengan menghitung berat ideal dari ibu hamil tersebut. Berat badan ideal didapatkan dari perhitungan antara tinggi badan dan usia kandungan. Setelah berat badan ideal ibu hamil diketahui, maka selanjutnya jumlah kalori diperhitungkan. Cara menghitung jumlah kalori yang dibutuhkan ibu hamil dengan kehamilan normal adalah dengan menggunakan metode Cooper. Metode Cooper menghitung kalori dengan mengolah berat badan ideal ibu hamil, aktifitas ibu hamil, serta jumlah jam tidur ibu hamil.

Menghitung kebutuhan energi ibu hamildengan menggunakan metode Cooper menggunakanpersamaan 1 sampai 7: [5]

$$
\begin{aligned}
& \mathrm{TEE}=\mathrm{AMB}-\mathrm{KT}+\mathrm{AF}+\mathrm{SDA}(1) \\
& \text { Dimana : } \\
& \mathrm{BBI}=90 \% \mathrm{x}(\text { Tinggi Badan }-100)(2) \\
& \mathrm{BBIH}=\mathrm{BBI}+(\text { Usia Hamil } \times 0,35)(3) \\
& \mathrm{AMB}=\mathrm{BBIH} \times 1 \times 24 \text { jam (4) } \\
& \mathrm{KT}=\mathrm{BBIH} \times 0,1 \times \text { jam tidur }(7 \mathrm{jam}) \\
& \text { (5) } \\
& \mathrm{AF}=\% \text { Aktifitas } \mathrm{x}(\mathrm{AMB}-\mathrm{KT})(6) \\
& \mathrm{SDA}=9 \% \times(\mathrm{AMB}-\mathrm{KT}+\mathrm{AF})(7) \\
& \text { Keterangan : } \\
& \text { TEE = Total Energy Expenditure } \\
& \mathrm{BBI}=\text { Berat Badan Ideal } \\
& \mathrm{BBIH}=\text { Berat Badan Ibu Hamil } \\
& \mathrm{AMB}=\text { Angka Metabolisme Basal } \\
& \text { KT }=\text { Koreksi Tidur } \\
& \mathrm{AF}=\text { Aktivitas Fisik } \\
& \text { SDA = Spesific Dinamic Action }
\end{aligned}
$$

Aktifitas fisik terbagi dalam 5 kelompok yaitu kategori istirahat (10\%), sangat ringan (30\%), ringan $(50 \%)$, sedang $(75 \%)$, dan berat $(100 \%)$. Untuk menghitung kebutuhan protein, lemak, dan karbohidrat dapat diperoleh dengan persamaan 8

sampai 10:

$$
\begin{aligned}
& \text { Karbohidrat }=60 \% \times \text { TEE }(8) \\
& \text { Lemak }=25 \% \times \text { TEE }(9) \\
& \text { Protein }=15 \% \times \text { TEE }(10)
\end{aligned}
$$

\section{ANALISA DAN HASIL \\ Analisa Sistem Yang Sedang Berjalan}

Informasi akan sistem Konsultasi gizi pada ibu hamil pada saat ini di Puskesmas Bungus Teluk Kabung Padang masih bisa dikatakan awam, yang mana para ibu hamil masih kurang peduli terhadap pemenuhan gizi mereka yang akan mempengaruhi kondisi janin yang sedang mereka kandung. Dalam Software Konsultasi gizi mereka lebih mementingkan makanan apa yang mereka suka tanpa memperhatikan jumlah kalori yang harus dipenuhi dalam tiap masa kehamilan. Informasi tentang gizi akan mereka dapatkan jika ada niatnya para ibu hamil untuk menemui ahli gizi dalam menanyakan berapa banyak pemenuhan gizi agar sang ibu dan janin bisa dalam keadaan sehat. Informasi yang akan diberikan oleh ahli gizi dapat memberitahukan jumlah kalori yang harus dikonsumsi tiap periodenya yang mana ini akan membuat ibu 
hamil harus rajin pergi ke Puskesmas dan bertemu ahli gizi.

\section{Alternatif Pemecahan Masalah}

Setelah peneliti mendapatkan informasi terhadap sistem lama yang sedang berjalan, maka peneliti mulai melakukan perancangan sistem baru yang mana dapat membantu mengatasi permasalahan yang dihadapi oleh sistem lama dan juga dapat menggantikan sistem yang saat ini sedang berjalan.Sistem ini diharapkan bisa membantu para pihak gizi di Puskesmas Bungus Teluk Kabung Padang untuk dapat memberikan informasi yang up to date bagi ibu hamil dan juga dapat menghemat waktu ibu hamil agar tidak terlalu sering menemui ahli gizi untuk melakukan konsultasi gizi di Puskesmas Bungus Teluk Kabung Padang.

\section{Gambaran Umum Sistem}

Pengguna dari aplikasi penentuan menu makanan harian ibu hamil berbasis web ini adalah seluruh ibu hamil yang terkoneksi internet dan mampu menggunakan internet. Sistem software konsultasi gizi menu makanan ibu berbasis web ini berfungsi untuk menentukan menu makanan harian ibu hamil berdasarkan atas kebutuhan gizi ibu hamil.

Proses penentuan menu makanan harian ibu hamil ini dimulai dari menghitung berat badan ideal yang harus dicapai oleh ibu hamil. Berat badan ideal dihitung berdasarkan tinggi badan dan usia kandungan dari sang ibu.
Setelah berat badan ideal didapatkan, langkah selanjutnya adalah menghitung kebutuhan kalori harian ibu hamil. Ada tiga tahapan dalam menghitung kalori harian ibu hamil. Perhitungan kalori harian ibu hamil berdasarkan pada berat badan ideal, jumlah jam tidur ibu hamil, dan tingkat aktifitas yang dilakukan oleh ibu hamil. Kebuutuhan kalori harian ibu hamil nantinya akan dijadikan sebagai dasar pembuatan menu makanan yang dikonsumsi oleh ibu hamil. Setelah jumlah porsi dan takaran diketahui maka selanjutnya adalah mencari menu makanan yang sesuai dengan kebutuhan ibu hamil tersebut.

Proses pembuatan menu makanan itu dilakukan dengan cara mengkombinasikan setiap menu yang ada pada data base sampai memenuhi kebutuhan gizi ibu hamil tersebut. Sebagai dasar pembuatan desain awal dari aplikasi konsultasi gizi ibu hamil ini mendapatkan bimbingan langsung dari ahligizi yang berada pada puskesmas bungus teluk kabung dan ibu hamil. Setelah proses pembuatan menu makanan tersebut selesai maka menu makanan tersebut dapat disarankan kepada ibu hamil.

\section{Perancangan Dengan UML Use Case Diagram}

Rancangan Use CaseDiagram pada Software Konsultasi Kebutuhan Gizi Ibu hamil pada Puskesmas Bungus Teluk Kabung Padang.

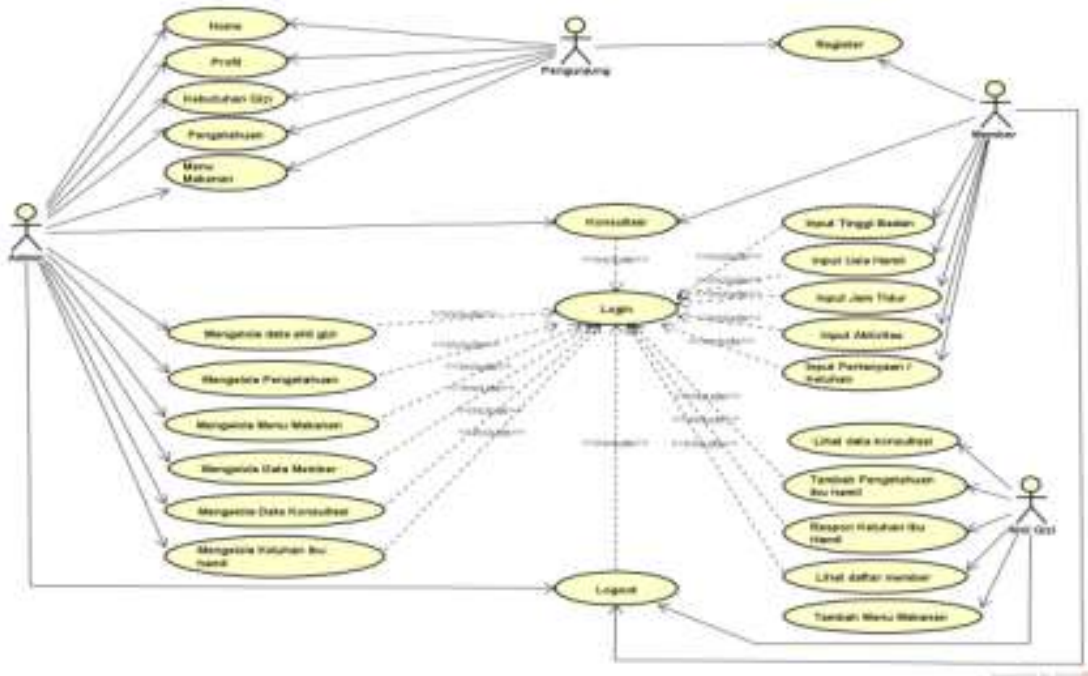

Gambar 1.Use Case Diagram

Activity Diagram 
Activity Diagram adalah teknik untuk mendeskripsikan logika prosedural, proses bisnis dan aliran kerja yang memungkinkan setiap pengguna dalam melakukan pilihan terhadap sistem.

Activity Diagram Admin
Activity

diagram

$\operatorname{admin}$ menggambarkan segala aktivitas yang bisa dilakukan admin, Dimulai dengan melakukan login terlebih dahulu untuk bisa memilih aktivitas yang akan dilakukan melalui menumenu pilihan yang ada.

\section{Activity diagram Ahli Gizi}

Activity diagram ahli gizi menggambarkan segala aktivitas yang bisa dilakukan admin, Dimulai dengan melakukan
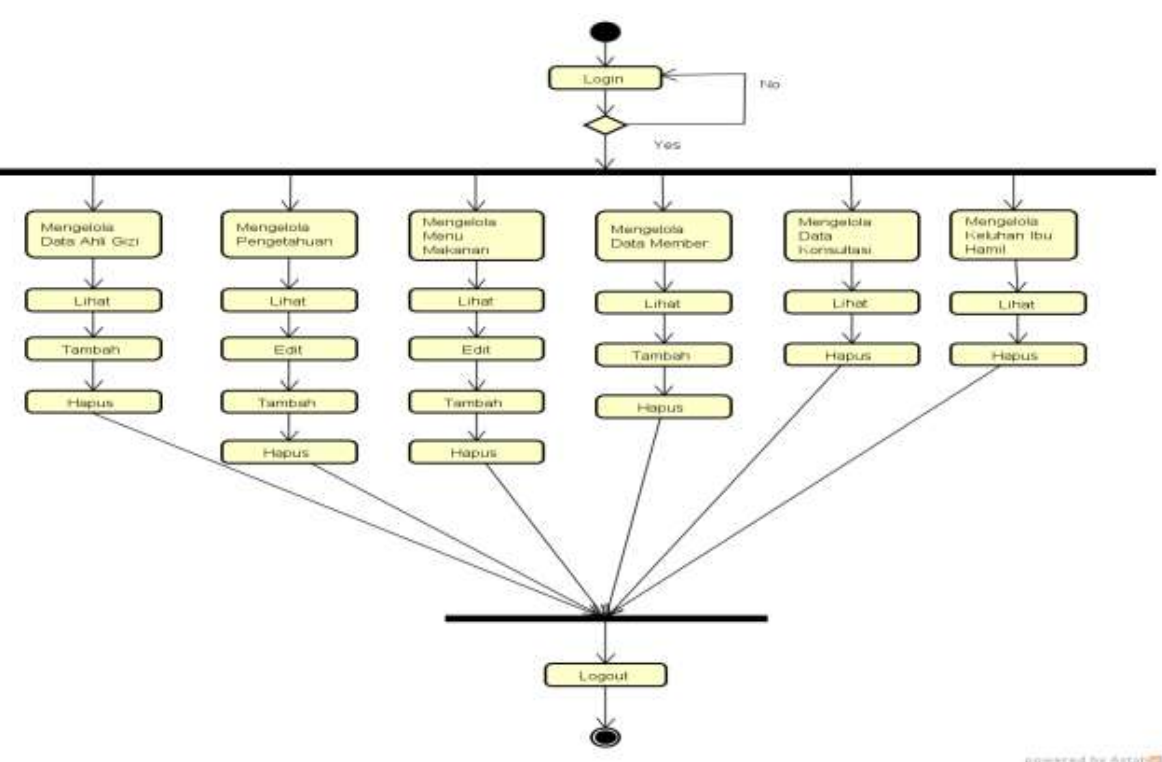

Gambar 2 Activity Diagram Admin

login terlebih dahulu untuk bisa memilih aktivitas yang akan dilakukan melalui menumenu pilihan yang ada.

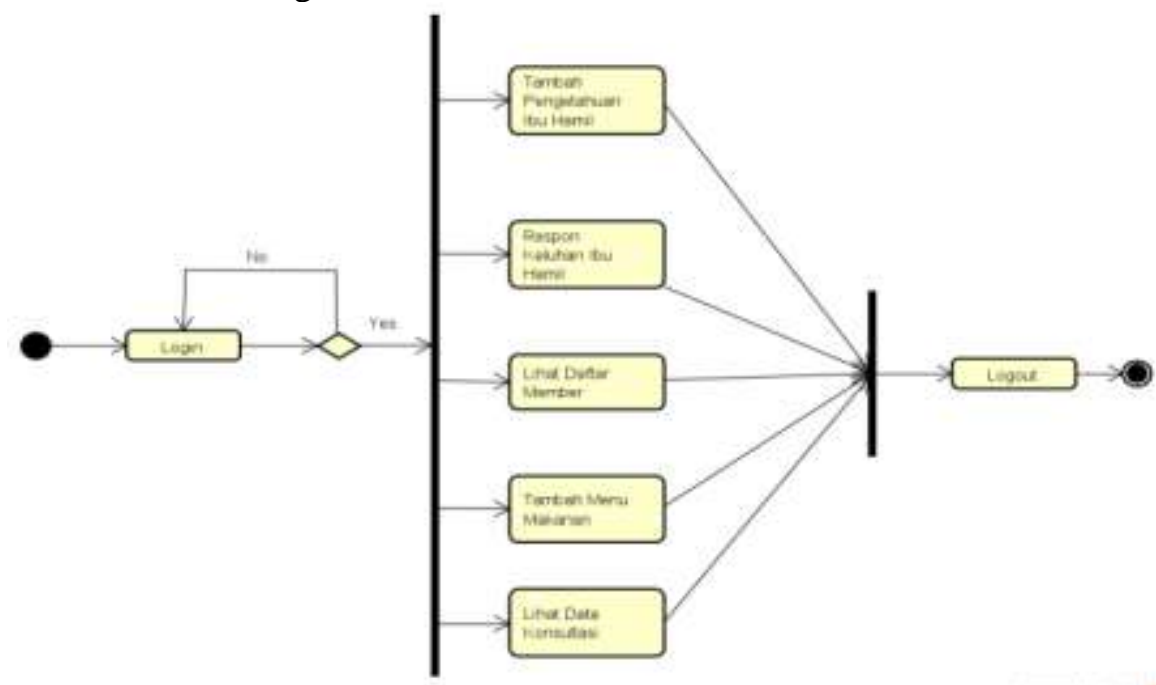

Gambar 3 Activity Diagram Ahli Gizi

Activity diagram Member

Activity diagram member menggambarkan segala aktivitas yang bisa dilakukan admin, Dimulai dengan melakukan login terlebih dahulu untuk bisa memilih aktivitas yang akan dilakukan melalui menumenu pilihan yang ada. 


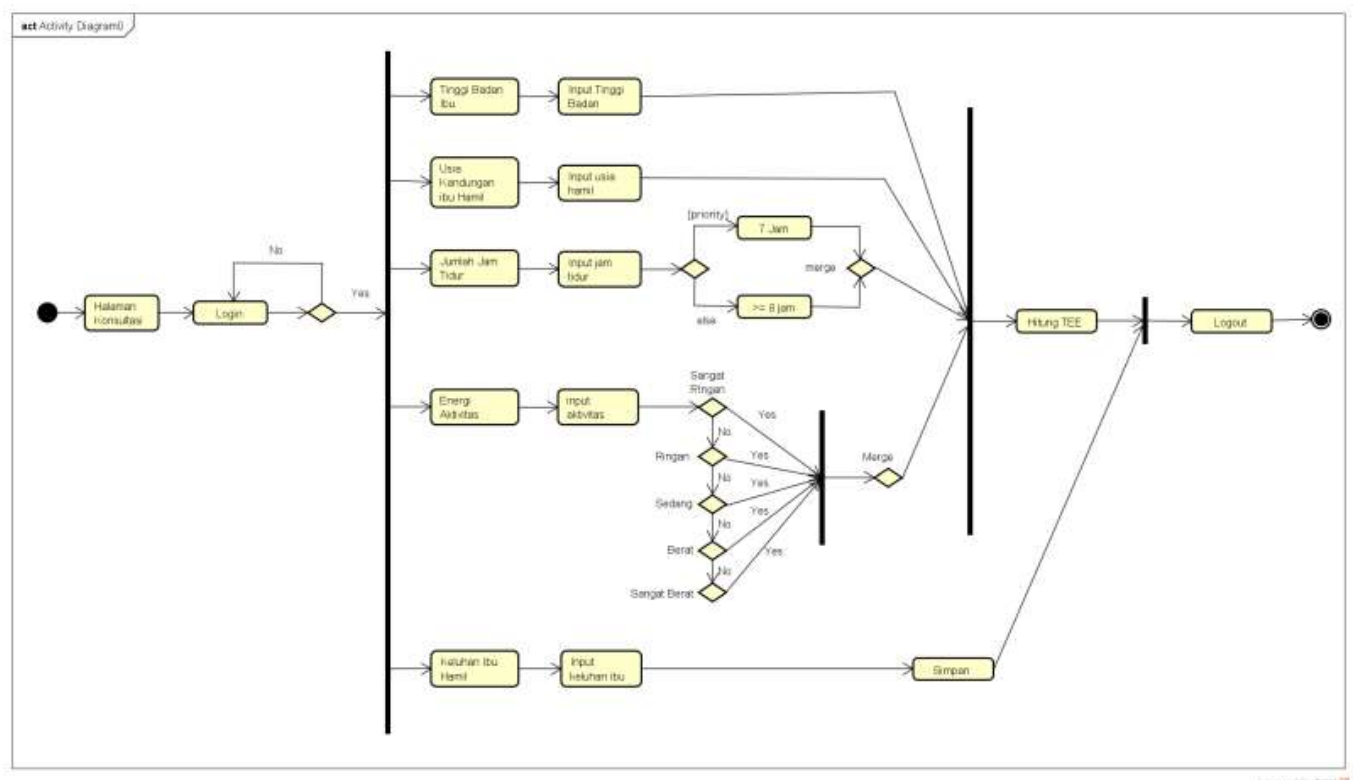

Gambar 4 Activity Diagram Member

\section{Activity Diagram Pengunjung}

Aktivity diagram pengunjung adalah aktivitas yang dilakukan oleh pengunjung terhadap sistem yang mana aktivitas tersebut tidak perlu dilakukan dengan login terlebih dahulu.

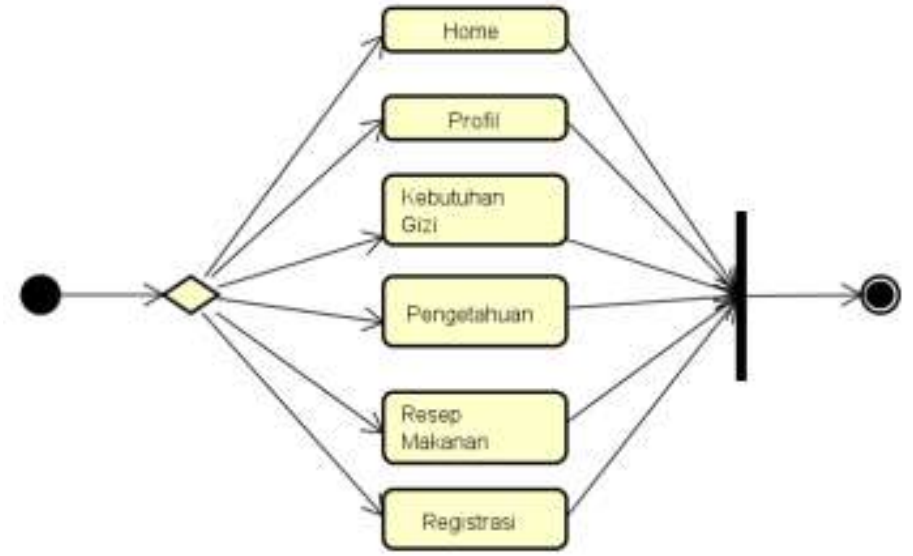

\section{Class Diagram}

Rancangan

Gambar 5 Activity Diagram Pengunjung

pada Puskesmas Bungus Teluk Kabung aplikasi Software Konsultasi gizi ibu hamil 


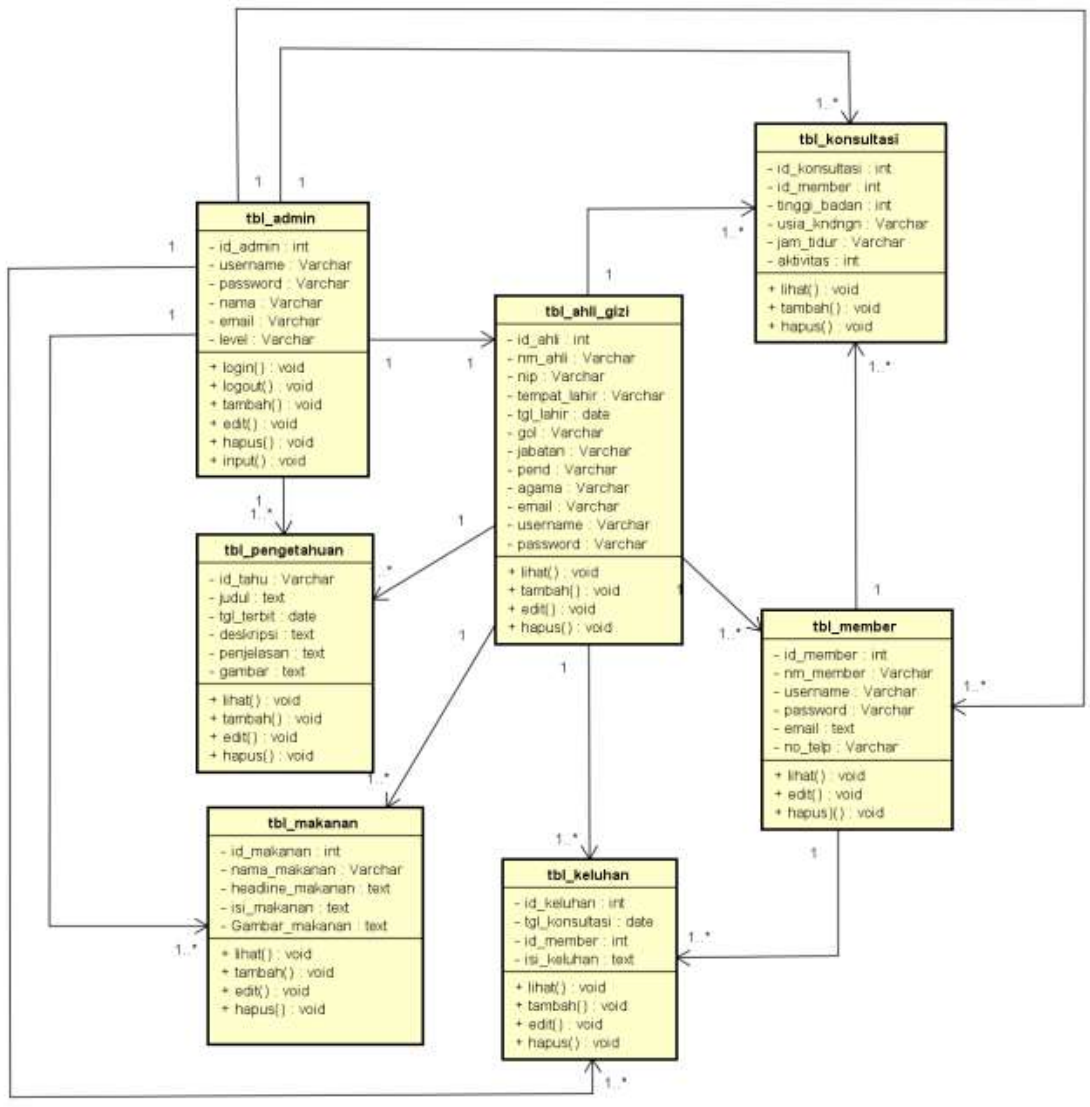

Gambar 6 Class Diagram

\section{IMPLEMENTASI SISTEM}

\section{Implemetasi Sistem}

Implementasi terhadap sistem dilakukan untuk mengetahui sejauh mana sistem yang dirancang dapat mengatasi masalah, serta untuk mengetahui hubungan antar komponen sistem, berikut beberapa bentuk hasil Software Konsultasi gizi ibu hamil dengan metode cooper pada Puskesmas Bungus Teluk Kabung Padang.

\section{Halaman Utama}

Halaman utama akan menampilkan profil tentang puskesmas bungusdan ahli gizi yang akan merespon konsultasi, kebutuhan gizi, pengetahuan gizi ibu hamil, resep makanan yang baik selama kehamilan dan juga registrasi member jika pengunjung ingin bergabung dan melakukan konsultasi.

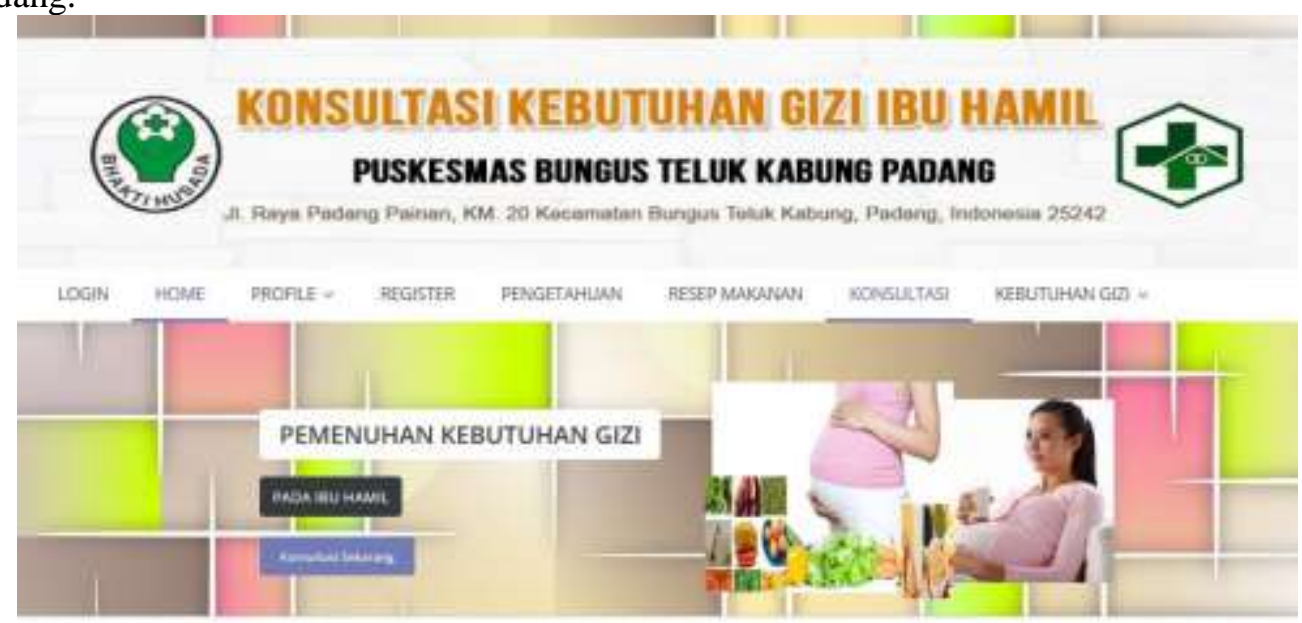

Gambar 7 Tampilan Halaman Utama 
Vol. 2 No.2 Juni 2019

http://jurnal.umsb.ac.id/index.php/RANGTEKNIKJOURNAL

\section{Halaman Input Data Ahli Gizi}

Halaman input data ahli gizi akan menampilkan isian formulir data untuk informasi database dari para ahli gizi yang menjadi konsultan dalam gizi ibu hamil.

\section{Halaman Login member}

Sebelum masuk pada halaman member, pengunjung diminta untuk memasukkan id user dan password yang sesuai saat pengunjung melakukan pendaftaran.

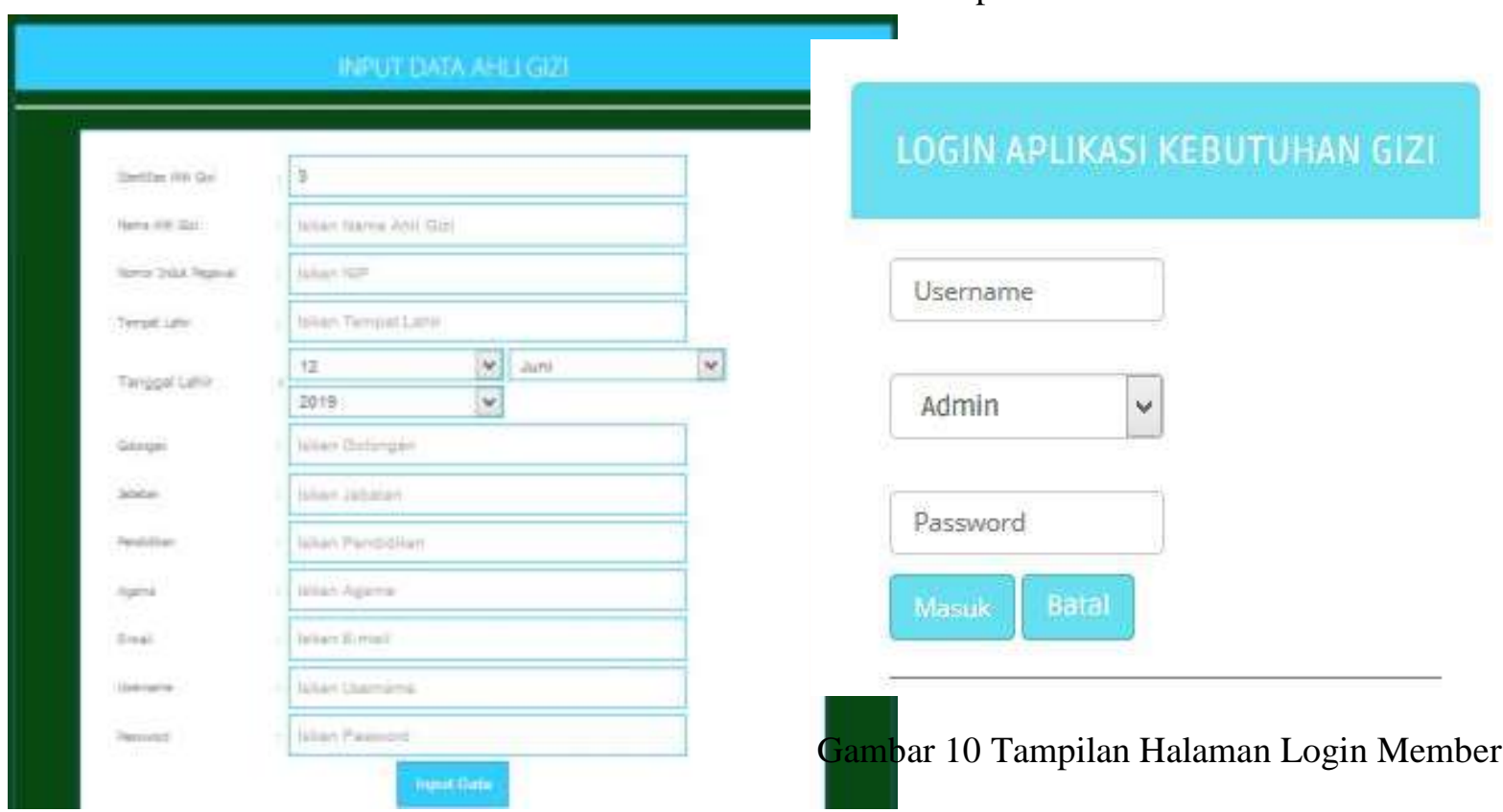

Gambar 8 Tampilan Halaman Input Data Ahli Gizi

\section{Halaman Registrasi Member}

Pada halaman ini pengunjung yang ingin menggunakan aplikasi pemenuhan Software Konsultasi gizi ibu hamil lebih lanjut, harus melakukan pendaftaran terlebih dahulu.

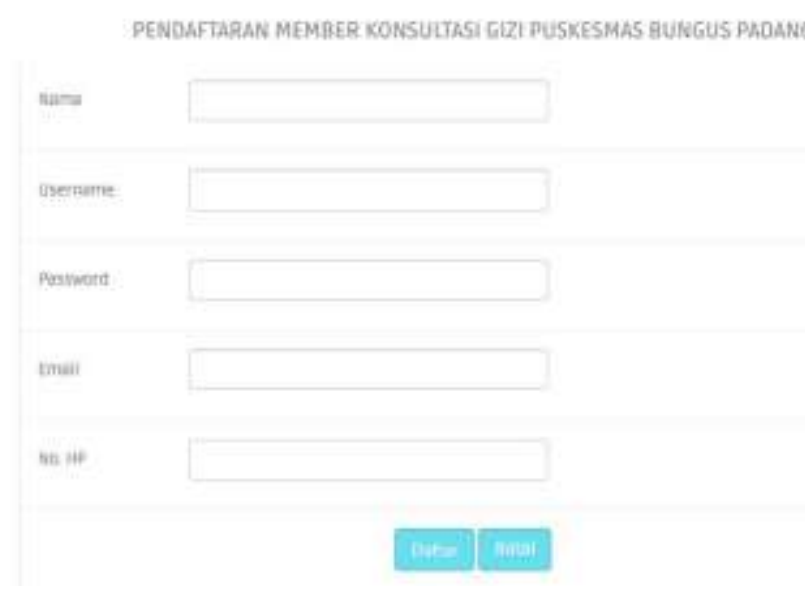

Gambar 9 Tampilan Halaman Registrasi Member

\section{Halaman Input Konsultasi Member}

Halaman input konsultasi member menampilkan isian data yang dibutuhkan untuk dianalisa oleh sistem software konsultasi kebutuhan gizi ibu hamil.

KONSULTASI KEBUTUHAN GIZI IBU HAMIL

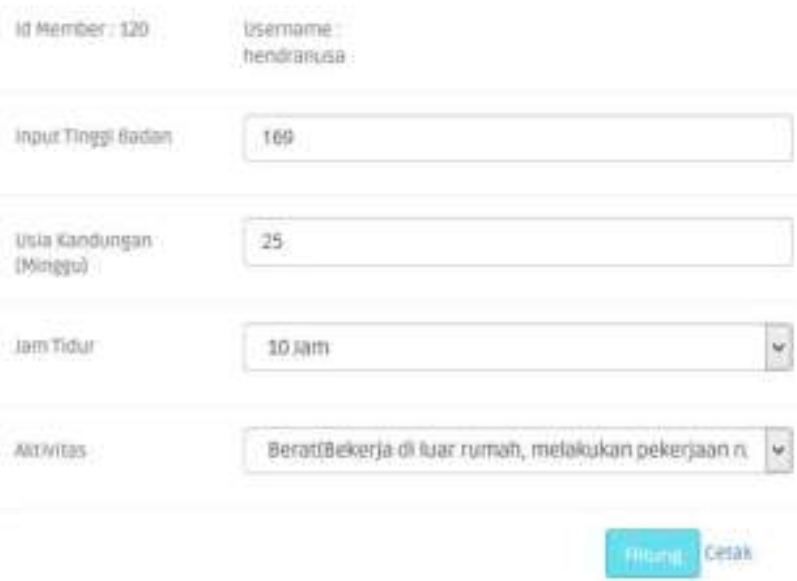

Gambar 11 Tampilan Halaman Input Konsultasi Member 
Vol. 2 No.2 Juni 2019

http://jurnal.umsb.ac.id/index.php/RANGTEKNIKJOURNAL

Rang Teknik Journal

Halaman Print Out Laporan Konsultasi member

Halaman print out laporan konsultasi member ini merupakan hasil dari analisa data yang telah diinputkan oleh member, dan menampilkan beberapa informasi mengenai kebutuhan energi untuk ibu hamil dan makanan apa yang direkomendasikan untuk bisa dikonsumsi.

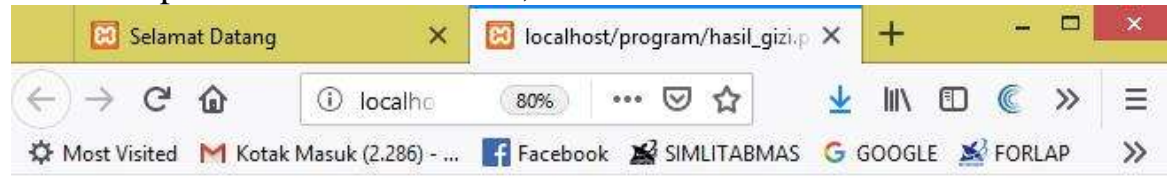

\section{DATA INFROMASI KEBUTUHAN GIZI IBU HAMIL PADA PUSKESMAS BUNGUS TELUK KABUNG PADANG}

LAPORAN DATA HASIL KONSULTASI

Tanggal : 12 /06/2019

\begin{tabular}{|l|l|}
\hline Nama & hendra \\
\hline Tinggi Badan & $169 \mathrm{Cm}$ \\
\hline Usia Kandunagn & $25 \mathrm{Minggu}$ \\
\hline Jam Tidur & $10 \mathrm{Jam}$ \\
\hline Aktivitas & 0.100 \\
\hline Total Energi & 1953.83045 \\
\hline Kebutuhan Kabohidrat & $1172.29827 \mathrm{Kkal}$ \\
\hline Kebutuhan Lemak & $488.4576125 \mathrm{Kkal}$ \\
\hline Kebutuhan Protein & $293.0745675 \mathrm{Kkal}$ \\
\hline
\end{tabular}

Keterangan :

Dari jumlah kalori yang diketahui, Maka Kami merekomendasikan Menu Makanan Yang akan baik dikonsumsi :

Pagi

$11 / 2$ gelas nasi, 1 butir telur di goreng pakai minyak zaitun, 1 mangkok kecil sayur.

Snack

1 potong buah apel merah

Siang

$11 / 2$ gelas nasi, 1 potong daging ayam goreng, 1 potong tempe, 1 mangkok kecil sayur cah kangkung.

Snack

1 potong buah pepaya, 1 mangkok kecil kacang-kacangan.

Malam

1 gelas nasi, 1 potong daging ayam goreng, 1 potong tempe/tahu, 1 mangkok kecil sayur cah kangkung.

Gambar 12 Tampilan Halaman Laporan Hasil Konsultasi

\section{Halaman Administrator}

Halaman administrator adalah halaman

yang ada di website kebutuhan gizi pada

\section{dimana admin dapat mengelolah semua content}

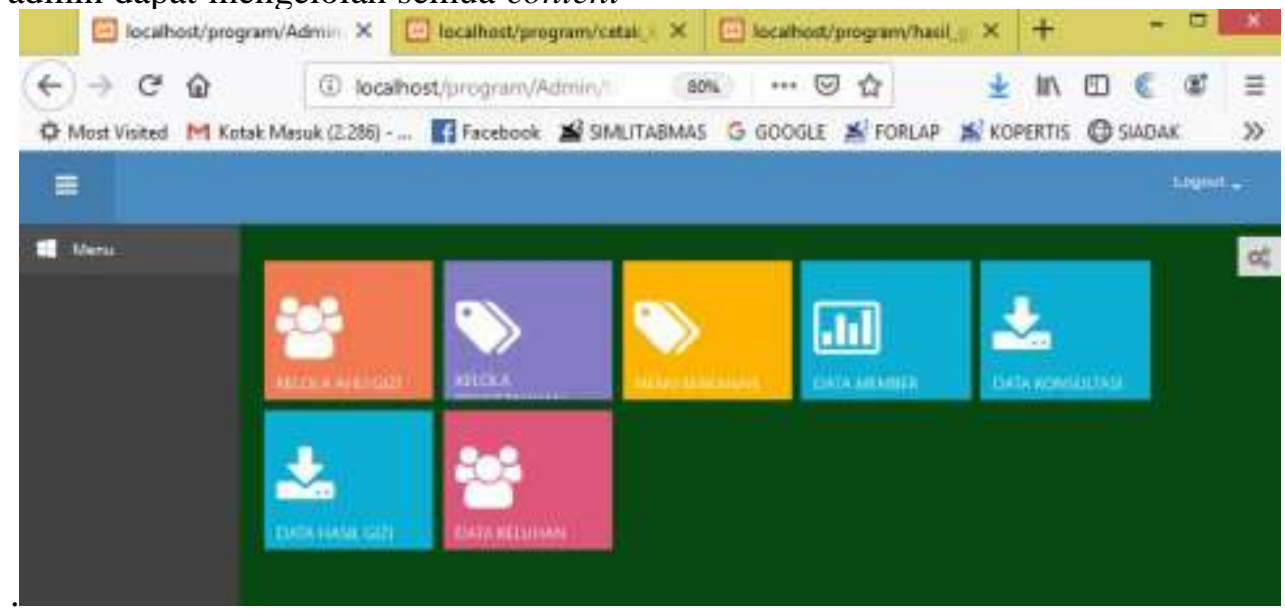

Gambar 13 Tampilan Halaman Administrator 


\section{PENUTUP}

Berdasarkan dari pembahasan bab-bab sebelumnya dan setelah dibuatnya aplikasi Konsultasi gizi ibu hamil dengan metode cooper berbasis website pada Puskesmas Bungus Teluk Kabung Padang maka dapat ditarik kesimpulan sebagai berikut:

1. Dengan adanya Sistem Konsultasi gizi ibu hamil berbasis website pada Puskesmas Bungus Teluk Kabung Padang ibu hamil dapat mengetahui kebutuhan gizi tiap priode kehamilan yang diperlukan untuk ibu dan janin.

2. Dengan sistem ini dapat memberitahukan informasi-informasi up to date terhadap perkembangan status gizi dan faktor-faktor yang mempengaruhi gizi.

3. Sistem menyajikan informasi resep makanan sehat yang sesuai kalori, karbohidrat, lemak dan protein yang sesuai takaran ibu hamil.

4. Sistem Informasi Konsultasi gizi ibu hamil berbasis website ini bisa menjadi wadah informasi terpercaya yang pengelolaannya dilakukan oleh ahli gizi Puskesmas Bungus Teluk Kabung Padang.

5. Sistem Informasi Konsultasi gizi ibu hamil berbasis website pada Puskesmas Bungus Teluk Kabung Padang dapat membantu ibu hamil dalam melakukan konsultasi gizi online dan merekomendasikan menu makanan sehat sesuai kalori yang dibutuhkan.

\section{REFERENSI}

[1] Suttabri Tata.2012: Analisis Sistem Informasi. Yogyakarta : Andi Offset

[2] Pratama, I Putu Agus Eka.2014.Sistem Informasi Dan Implementasinya.

Bandung:Informatika

[3] Kadir , Abdul.2014 Pengenalan Sistem Informasi. Yokyakarta : Andi Offset

[4] A S, Rosa dan M. Shalahuddin. 2015. Rekayasa Perangkat Lunak. Bandung : Informatika

[5] Agung, M Leo. 2016: Pemograman PHP dan MySQL untuk pemula. Yogyakarta : Andi offset

[6] Kusrini, Konsep dan Aplikasi Sistem Pendukung Keputusan. Yogyakarta :Andi,2007
[7]Ester Ratna Ningsih. 2010. Gambar Krakteristik ibu hamil, tingkat pengetahuan serta Sikap terhadap Asupan Gizi Ibu Hamil dirumah sakit Panti Wilasa "Citarum". Jurnal Kebidanan Panti Wilasa. Vol 1. No. 1

[8] Igusti Bagus Ngurah Surya Atmaja,Januar Wibowo,2012. Rancang Bangun aplikasi penentuanmenu makanan ibu hamil menggunakan metode cooper. Jurnal JSIKA. Vol 1. No. 1

[9] Siti Indeawati, 2015. Hubungan status ibu hamildengan kejadian BBLR diwilayah Puskesmas Minggir Kabupaten Sleman [Skripsi]. Yogyakarta (ID) : STIKES Aisyiyah Yogyakarta

[10] Putri Desmiwati, Febryanantanuji, 2014. Sistem Informasi pemenuhan gizi melalui Menu Makanan Menggunakan Metode Cooper Berbasis Website [Skripsi]. Semarang (ID) : STEKOM Semarang 